\title{
Financial Health of Urban Local Bodies of Rajasthan with Special Reference to Jodhpur Municipal Corporation
}

\author{
Saruparia Chitra \\ Assistant Professor, Faculty of Policy Science, National Law University, Jodhpur..INDIA
}

\begin{abstract}
Urban Local bodies (ULB's) in India are facing resource constraint and so they are incapable to perform their functions efficiently. On the other hand their expenditures are increasing enormously. So the gap between the income and expenditure of urban local bodies is portraying a financial crisis, which needed to be cured urgently. Also ULB's have little functional and financial autonomy under the existing legal framework. This paper is study of urban local bodies of Rajasthan with special reference to Jodhpur Municipal Corporation (JMC) Jodhpur. The present study investigates the financial health of JMC and suggests measures to improve their financial health.

Keywords: financial stress, Seventy fourth Constitutional Amendment (CAA), urban local bodies, urbanization.
\end{abstract}

\section{Introduction}

Urban Local bodies in India are facing resource constraint and so they are incapable to perform their functions efficiently. On the other hand their expenditures are increasing enormously. So the gap between the income and expenditure of urban local bodies is portraying a financial crisis, which needed to be cured urgently. This paper is study of urban local bodies of Rajasthan with special reference to Jodhpur Municipal Corporation (JMC) Jodhpur. The present study investigates the financial health of JMC and suggests measures to improve their financial health.

There are 183 urban local bodies in Rajasthan consisting of 3 Municipal corporations, 11 municipal councils, 169 Municipal Board (consisting of Class II, III, IV cities) with a population of 13.2 million (24 percent). Jaipur is the largest city of Rajasthan with over three million population. Jodhpur is the second largest city of Rajasthan with 3.68 million. .In additions there are 18 cities with more than one lakh population. The urban area of Rajasthan is spread over $5.43(000 \mathrm{sqkm})$, which is 1.68 percent of the total area. Thus the urban density of Rajasthan is 2431 per square kilometer compared to India's urban density of 3572 per square kilometer. Urban population of Rajasthan increased at the rate of 2.7 percent per annum during 1991-2001 at same ra te at which the total population of Rajasthan is increasing. Urbanization of Rajasthan has slowed down over time.

Rajasthan is not a highly urbanized state. According to the projections by Registrar General, Government of India urban population of Rajasthan is likely to increase to 23.7 million (29 percent) of the likely population of 81.5 million by 2026 at average annual compound growth rate of 2.3 percent during 2001 2026.Thus Rajasthan is going to remain largely a rural economy. This paper is study of urban local bodies of Rajasthan with special reference to Jodhpur Municipal Corporation (JMC) Jodhpur.

\section{Objectives of the study}

The present study aims

1. to understand the basic legal framework for urban local bodies of Rajasthan

2. to study the growth of Jodhpur and Jodhpur Municipal Corporation.

3. to examine the fiscal health of JMC.

\section{Legal Framework}

The urban local bodies of Rajasthan are governed by Rajasthan Municipal Act 1959 (RMA-1959) irrespective of the size or the class of the city. This Act was amended in 1994 by incorporating 74th Constitutional Amendment Act (CAA) of India giving urban local bodies a constitutional status so that they may perform effectively by providing them basic functional and financial autonomy. Seventy fourth Constitutional Amendment Act (CAA) provides reservation of seats to scheduled castes, scheduled tribes and women, fixity of tenures of five years to ULB's, setting up a State Election Commission and that of State Finance Commission every five year to examine the financial strength of the Panchayati Raj Institutions (PRIs) and Urban Local Bodies (ULB's). It also recommends principles to determine taxes which can be assigned to the municipalities and PRI's , tax sharing between the Urban local bodies and grant- in- aid to the ULB'sand PRI's from the consolidated fund of the state. 
The Amendment also includes Schedule XI and XII giving an indicative list of functions to be performed by PRI's and ULB's. Inspite of 74 th CAA the basic legal framework for ULB's of Rajasthan as laid down in RMA1959 before 1994 remains unaltered. The ULB's of Rajasthan are highly regulated and controlled by Department of Local Self Government, Government of Rajasthan. The ULB's do not have any autonomy to determine priorities, discontinue schemes, and change the composition of expenditure. The functions laid down in the law largely remain same as it was before 74 th CAA. The Budget proposal has to be sanctioned by government proposed by the ULB. The staffing of ULB's are also laid down under the law requiring approval at every stage. This is contrary to the intention and objective of the 73rd and 74 th CAA. Thus ULB's have very little functional and financial autonomy under the existing legal framework.

\subsection{Preparation of the Budget Estimates by Municipalities}

Rajasthan Municipal Act 1959 and Rajasthan Nagarpalika (Budget Rules) 1966 elaborates the method for preparation of the Budget by the ULB's. There is a printed format circulated by Department of Local selfgovernment, Government of Rajasthan in which the budget proposal has to be submitted to State government for its sanction. The budgets are under two heads -Revenue and Capital for both income and expenditure. The revenue income consists of income from own taxes consisting of the octroi and house tax which are obligatory, income from own non-tax from bye-laws, rules and regulations, income from the assets of the ULB, penalties and fines, income from commercial institutions and miscellaneous. The miscellaneous item includes the general-purpose grant in aid provided to local bodies under the General Purpose Grant in aid to Local Bodies Rules, 1964. The extent of grant under this may be sanctioned at the rate of Rs. 12.50 per capita of the population of the Municipal Corporations based on the last Census reports subject to the extent of budget provisions in a financial year. This grant- in- aid has to be kept in a separate bank account and can be only used for salaries and allowances of the staff. The government has also the option to deduct the amount due to the corporations up to fifty percent of the grant- in -aid. Grants received from State Finance Commission (SFC) are also included under this head.

The capital income consists of income from the sale of land, scheme specific assistance/grant including grant receipts from CFC and SFC, grant-in- aid for capital works of the nature of construction of roads, drains, stone pavements, public urinals and latrines which are of direct public utility to the extent of forty percent of the estimated costs of the works, from public works department, borrowings and other sources of income of capital nature. The components of revenue expenditure are general administration, expenditure on tax collection, public welfare and public health, public safety, street lighting, cattle houses, parks and public repair. Capital expenditure consists of development works from Municipal funds, from the grant in aid received, purchase of assets and payment of loans etc. According to Rule 18 of the Rajasthan Nagarpalika Budget Rules 1966 all urban local bodies must be allowed to balance at the end of the said year of not less than such sum as may from time to time be fixed by the state government which is presently $1 / 12$ of the revenue income ) .

\section{Jodhpur Municipal Corporation (J.M.C)}

Jodhpur is the second largest city of Rajasthan with a population of 8.6 lakh in 2001. City has shown substantial growth in terms of population and area under the jurisdiction of JMC during 1991-2001. The population of JMC has increased from 6.66 lakh in 1991 to 8.60 lakh in 2001 at an annual compound growth rate of 2.54 percent per annum which is lower than the rate of growth of the population of urban Rajasthan. The area of JMC has increased from 78.60-sqkm in 1991 to $90.34 \mathrm{sqkm}$ in 2001 . The density of the city has increased from 8477 per sqkm in 1991 to over 9519 per sqkm in 2001. The population of JMC accounts for 6.6 percent of the urban population of Rajasthan and the area of JMC accounts for 1.66 percent of the urban area of Rajasthan. The area and population of Jodhpur will increase in next twenty-five years. According to Census 2011 the population of Jodhpur city is 36 lakh. The Master Plan of Jodhpur 2001-2023 by Department of Town Planning estimates that likely population of Jodhpur by 2023 will be 22 Lakh. However, demographic indicators for 2001-2025 for Rajasthan present a different picture. As per the projections by Registrar General, G.O.I the population growth rate of Rajasthan will decline from 1.9 percent to 1 percent, birth rate from 27.1 to 16.7 , death rate from 7.0 to 6.4 and infant mortality rate from 71.4 to 47.5 , under five mortality rate from 99.8 to 66.4 , total fertility rate from 3.6 to 2.0, life expectancy of males will increase from 64.1 years to 69.6 and that of females from 67.2 to 73.1 during 2001-25. This obviously means that the population growth rate in rural and urban areas including Jodhpur will substantially slow down. Therefore the assumption of the Department of town planning that Jodhpur population will increase from 8.6 Lakh in 2001 to 22 Lakh by 2023 at the rate of 4 percent p.a. is unrealistic. Also according to the Census 2011, it is already 36 Lakh.

The work force in Jodhpur has increased from 1.86 Lakh to 2.87 Lakh at the rate of 3.16 percent p.a during 1991-2001. In 1991 about 20 percent of the persons were engaged in industries, 19 percent in trade and commerce, 34 percent in other services, 9 percent in transport and communications, 8 percent in construction and 7 percent in agriculture and allied. There is also substantial growth in the economic activities and prosperity 
under the jurisdiction of JMC since 1991 after liberalization. It can be visualized in terms of increasing vehicles, parks, posh hotels, interior and externally decorated bungalows, private schools of national and international standards and private hospitals etc. Therefore it is presumed that the revenues and expenditures of JMc's would have also grown as well.

\subsection{Finances of Jodhpur Municipal Corporation (JMC)}

Budget estimates are proposed by JMC in the prescribed format of the Government of Rajasthan as approved by the finance committee and the general body and then sent to the Department of Local SelfGovernment, Government of Rajasthan for sanction under RMA 1959. Centre and State Budgets are approved by respective elected bodies whereas in case of ULB's in Rajasthan finance committee and general body approves the budget estimates and forwards it to state government which is the sanctioning authority for the budgets. The State Finance Commission needs to look into this anomaly with respect to different procedure being followed in case of local bodies even though they are Constitutional entity and elected body.

\subsubsection{Trends in Budgets Heads of JMC}

Table 1 provides the overall financial strength of JMC for the period 1994-95 to 2007-08.

Table: 1

Trends in Revenue Income, Revenue Expenditure, Capital Income, Capital Expenditure, Total Income and Total Expenditure, 1994-95 to 2007-08 (in Rs. Crores)

\begin{tabular}{|c|c|c|c|c|c|c|}
\hline Year & $\begin{array}{c}\text { Rev. Income } \\
\text { (percentage change) }\end{array}$ & Rev.Exp & Cap Income & Cap.Exp & Total Income & $\begin{array}{c}\text { Total } \\
\text { Expenditure }\end{array}$ \\
\hline $1994-95$ & 13.4 & 10.95 & 1.26 & 4.24 & 14.66 & 15.19 \\
\hline 1995-96 & $19.03(42.0 \%)$ & $\begin{array}{c}12.5 \\
(14.1 \%) \\
\end{array}$ & $2.41(91.2 \%)$ & $5.77(36 \%)$ & $21.44(46.2 \%)$ & $18.27(20.2 \%)$ \\
\hline 1996-97 & $18.93(-0.5 \%)$ & $\begin{array}{l}15.84 \\
(26.7) \\
\end{array}$ & $3.79(57.2 \%)$ & $9.45(63 \%)$ & $22.72(5.9 \%)$ & $25.29(38.4 \%)$ \\
\hline $1997-98$ & 19.48 & 17.35 & 7.02 & 6.16 & 26.5 & 23.51 \\
\hline 1998-99(R) & 31.81 & 31.42 & 15.19 & 18.08 & 47.0 & 49.5 \\
\hline 1999-2000 & 22.25 & 23.40 & 3.47 & 2.41 & 25.72 & 25.81 \\
\hline 2000-01 & $24.32(9.3 \%)$ & $\begin{array}{l}25.66 \\
(9.6 \%)\end{array}$ & $5.33(53.6 \%)$ & $5.75(138 \%)$ & $29.65(15.2 \%)$ & $31.41(21.6 \%)$ \\
\hline 2001-02 & $29.26(20.3 \%)$ & $\begin{array}{c}26.16 \\
(1.94 \%) \\
\end{array}$ & $8.33(56.2 \%)$ & $8.07(40.3)$ & $37.59(26.77 \%)$ & $34.23(8.9 \%)$ \\
\hline 2002-03 & $28.59(-2.23)$ & $\begin{array}{l}27.56 \\
(5.3 \%) \\
\end{array}$ & $5.39(-35.3)$ & $6.93(-14.12 \%)$ & $34.28(-8.8 \%)$ & $36.49(6.6 \%)$ \\
\hline 2003-04 & $30.39(5.1)$ & $29.38(6.6)$ & $7.44(38 \%)$ & $8.89(28.28)$ & $37.83(10.35 \%)$ & $38.27(4.8 \%)$ \\
\hline 2004-05 & $33.94(11 \%)$ & $\begin{array}{l}31.63 \\
(7.6 \%) \\
\end{array}$ & $8.96(20 \%)$ & $8.41(-5.4)$ & $42.9(13.4)$ & $40.04(4.6 \%)$ \\
\hline 2005-06 & $36.35(7.1)$ & $\begin{array}{c}36.04 \\
(13.9 \%) \\
\end{array}$ & $15.04(67.8 \%)$ & $12.98(11.98)$ & $51.39(19 \%)$ & $42.06(5 \%)$ \\
\hline 2006-07(S)* & $58.69(61 \%)$ & $\begin{array}{c}43.5 \\
(24.6 \%)\end{array}$ & $40.4(168)$ & $42.11(488 \%)$ & $99.09(92 \%)$ & $85.61(103 \%)$ \\
\hline 2007-08(B.E)** & $56.83(-3.2)$ & $\begin{array}{c}42.979(- \\
1.2 \%)\end{array}$ & $24.26(-39.9 \%)$ & $34.66(-17.7 \%)$ & 81.09 & 77.63 \\
\hline $\begin{array}{l}\text { Three Year } \\
\text { Average of } \\
1994-95 \text { to } 96- \\
97\end{array}$ & 17.12 & 13.1 & 2.48 & 6.48 & 19.6 & 19.58 \\
\hline $\begin{array}{l}\text { Three Year } \\
\text { Average of } \\
2003-4 \text { to } 05-06\end{array}$ & 33.49 & 32.95 & 10.48 & 10.09 & 44.04 & 40.12 \\
\hline$* * *$ AACGR & 7.74 & 10.56 & 17.36 & 5.02 & 9.4 & 8.3 \\
\hline
\end{tabular}

Note: Values in brackets shows the Annual percentage change

Where $\mathrm{P}=$ Proposed, $\mathrm{S}=$ Sanctioned, $* \mathrm{~B} . \mathrm{E}=$ Budget Estimates, $* * \mathrm{AACGR}=$ Average Annual Compound Growth Rate

Source: 1.Income-Expenditure estimates, 1998-99, Jodhpur Municipal Corporation

2. Income-Expenditure estimates, 2003-04Jodhpur Municipal Corporation

3. Income-Expenditure estimates, 2004-05, Jodhpur Municipal Corporation

4. Income-Expenditure estimates, 2006-07, Jodhpur Municipal Corporation

5. Annual Income -Expenditure Estimates, 2005-06, Jodhpur Municipal Corporation

6. Annual Income -Expenditure Estimates, 2006-07, 2007-08 Jodhpur Municipal Corporation

There are some important features of this time framework. The first is that this period is after liberalization. The second is 73rd and 74 th CAA were incorporated in their respective laws in 1994. So this is post- 73rd - 74 th 
CAA period and post liberalization period. Third feature is the abolition of octroi from Ist August 1998 and the introduction of compensation in lieu of octroi. From 23 rd February 2007 the property tax in Rajasthan has also being abolished and thus now onward there will be no own tax revenue of the ULB's in Rajasthan. Though the provisions with regard to octroi and property tax have been retained in the Law. Inspite of abolition of octroi during this period revenue income has grown at the rate of $7.79 \%$ p.a during 1994-95 to 2005-06. The reason seems to be that JMC continues to include compensation in lieu of octroi as own tax whereas the G.O.R in its Annual Report 2003-04 has shown the compensation in lieu of octroi as grant in lieu of octroi. The same revised classification has also been followed in report of the Twelfth Finance Commission (TFC).

The revenue income was stagnant for three years during 2001-02, 2002-03, and 2003-04. With these trends the estimates of revenue income of 2006-07 and Budget estimates of 2007-08 seems to be very unrealistic. The percentage increase between sanctioned revenue income 2006-07 and actual of 2005-06 is very high ranging from 25 percent to 488 percent, which is very unlikely. This raises apprehensions about the present sanctioning mechanism of the budget estimates of local bodies. Appendix "K" in the Rajasthan Nagarpalika Budget Rules, 1966 clearly mentions that the budget estimates should be realistic and achievable and the kind of increase shown in Budget estimates of 2007-08 is very unrealistic. The Rules expect that the reasons for such a huge increase should be mentioned in the budget papers, which has not been done in JMC budget.

The revenue expenditure has grown at the rate of 10.56 percent per annum compared to 7.74 percent growth of revenue income during this period reflecting growing gap between revenue income and revenue expenditure and consequent concealed deficit, which is not allowed under law to ULB's. The sanctioned estimates of 2006-07 shows budget surplus of Rs 15.1 crore which seems to be unrealistic because all through this gap was always less than one crore.

The trends in capital income and capital expenditure are contrary to revenue income and revenue expenditure. The capital income is growing at the rate of $17.36 \%$ p.a and capital expenditure only at the rate of $5.02 \%$ p.a. The reason could be that the funds could not be utilized and /or it could be that the funds flow may not be regular and at the end of the fag year and therefore they are not able to utilize and hence it has to be carried forward. E.g the funds allocated from Twelfth Finance Commission (TFC) were received by J.M.C on 31 st March, 2006. Therefore it had to be carried forward in 2006-07. The grant allocated by the National Finance Commission (NFC) is only released after the State Finance Commission (SFC) recommendations are received. Therefore this grant remains unutilized. The largest chunk of capital income is received under head eight of capital income consisting of tied grant for specific schemes and untied grants received from NFC and the SFC. The rate of growth of total income both revenue and capital income is $9.49 \%$ p.a but the total expenditure both revenue and capital is growing at the rate of $8.3 \%$ p.a.

\subsubsection{Trends in Revenue Income by Different Sources}

Trends in revenue income by own taxes (octroi and property tax) and by non-tax own source tax is presented in Table 2.

Table: 2

Trends in Revenue Income by Various Sources, 1994-95 to 2007-08 (in crores)

\begin{tabular}{|c|c|c|c|c|c|c|}
\hline Year & $\begin{array}{c}\text { Revenue from own taxes } \\
\text { (Octroi+Property) } \\
\text { (1) }\end{array}$ & Octroi & $\begin{array}{l}\text { Property } \\
\text { Tax }\end{array}$ & $\begin{array}{l}\text { Non-tax own } \\
\text { Revenue } \\
*(2)\end{array}$ & $\begin{array}{c}\text { Revenue } \\
\text { Grant-in aid } \\
\text { (3) }\end{array}$ & $\begin{array}{c}\text { Revenue } \\
\text { Income } \\
(1+2)\end{array}$ \\
\hline 1994-95 & $\begin{array}{c}11.86 \\
(87.85)\end{array}$ & $\begin{array}{c}11.79 \\
(87.98) \\
\end{array}$ & $\begin{array}{l}0.04 \\
(.29) \\
\end{array}$ & $\begin{array}{c}1.54 \\
(11.490 \\
\end{array}$ & $\begin{array}{c}0.67 \\
(5) \\
\end{array}$ & $\begin{array}{c}13.4 \\
(100) \\
\end{array}$ \\
\hline $1995-96$ & $\begin{array}{c}16.79 \\
(88.22) \\
\end{array}$ & $\begin{array}{c}16.71 \\
(87.80) \\
\end{array}$ & $\begin{array}{c}0.06 \\
(.031) \\
\end{array}$ & $\begin{array}{c}2.27 \\
(11.92) \\
\end{array}$ & $\begin{array}{l}0.83 \\
(4.3) \\
\end{array}$ & $\begin{array}{l}19.03 \\
(100) \\
\end{array}$ \\
\hline 1996-97 & $\begin{array}{c}16.78 \\
(88.64)\end{array}$ & $\begin{array}{c}16.72 \\
(88.32) \\
\end{array}$ & $\begin{array}{l}0.08 \\
(.42)\end{array}$ & $\begin{array}{c}2.15 \\
(11.35)\end{array}$ & $\begin{array}{l}0.83 \\
(4.3)\end{array}$ & $\begin{array}{l}18.93 \\
(100)\end{array}$ \\
\hline $\begin{array}{l}1997-98 \\
\end{array}$ & 15.25 & $\begin{array}{c}15.15 \\
(77.77)\end{array}$ & $\begin{array}{l}.09 \\
(.46)\end{array}$ & 4.24 & 1.25 & $\begin{array}{l}19.48 \\
(100)\end{array}$ \\
\hline 1998-99(R) & 23.88 & $\begin{array}{c}23.50 \\
(73.87)\end{array}$ & $\begin{array}{l}.04 \\
(.12)\end{array}$ & 7.93 & 1.53 & $\begin{array}{l}31.81 \\
(100)\end{array}$ \\
\hline $1999-2000$ & $\begin{array}{c}18.91 \\
(84.98)\end{array}$ & $\begin{array}{c}18.88 \\
(84.85) \\
\end{array}$ & $\begin{array}{l}0.04 \\
(.17) \\
\end{array}$ & $\begin{array}{c}3.34 \\
(15.01) \\
\end{array}$ & $\begin{array}{l}1.56 \\
(7.0) \\
\end{array}$ & $\begin{array}{l}22.25 \\
(100) \\
\end{array}$ \\
\hline $2000-01$ & $\begin{array}{c}21.86 \\
(89.88) \\
\end{array}$ & $\begin{array}{c}20.76 \\
(85.36) \\
\end{array}$ & $\begin{array}{c}1.1 \\
(4.5)\end{array}$ & $\begin{array}{c}2.46 \\
(10.11)\end{array}$ & $\begin{array}{l}0.83 \\
(3.4) \\
\end{array}$ & $\begin{array}{l}24.32 \\
(100)\end{array}$ \\
\hline 2001-02 & $\begin{array}{c}23.51 \\
(80.34) \\
\end{array}$ & $\begin{array}{c}22.8 \\
(77.92) \\
\end{array}$ & $\begin{array}{l}0.71 \\
(2.4)\end{array}$ & $\begin{array}{c}5.75 \\
(19.65) \\
\end{array}$ & $\begin{array}{c}4 \\
(13.6)\end{array}$ & $\begin{array}{l}29.26 \\
(100)\end{array}$ \\
\hline $2002-03$ & $\begin{array}{c}23.62 \\
(82.61)\end{array}$ & $\begin{array}{c}22.89 \\
(80.06)\end{array}$ & $\begin{array}{l}0.73 \\
(2.5)\end{array}$ & $\begin{array}{c}4.93 \\
(17.26)\end{array}$ & $\begin{array}{c}2.46 \\
(8.60)\end{array}$ & $\begin{array}{l}28.59 \\
(100)\end{array}$ \\
\hline 2003-04 & $\begin{array}{c}24.55 \\
(80.78) \\
\end{array}$ & $\begin{array}{c}24.03 \\
(79.07)\end{array}$ & $\begin{array}{c}0.52 \\
(1.71) \\
\end{array}$ & $\begin{array}{c}5.83 \\
(19.18) \\
\end{array}$ & $\begin{array}{c}2.49 \\
(8.19)\end{array}$ & $\begin{array}{l}30.39 \\
(100)\end{array}$ \\
\hline 2004-05 & $\begin{array}{c}27.13 \\
(80.40) \\
\end{array}$ & $\begin{array}{c}26.44 \\
(78.36) \\
\end{array}$ & $\begin{array}{l}0.68 \\
(2.0) \\
\end{array}$ & $\begin{array}{c}6.62 \\
(19.62) \\
\end{array}$ & $\begin{array}{c}3.42 \\
(10.13) \\
\end{array}$ & $\begin{array}{l}33.74 \\
(100) \\
\end{array}$ \\
\hline
\end{tabular}




\begin{tabular}{|c|c|c|c|c|c|c|}
\hline $2005-06$ & $\begin{array}{c}28.32 \\
(77.90)\end{array}$ & $\begin{array}{c}27.53 \\
(75.73)\end{array}$ & $\begin{array}{c}0.79 \\
(2.17)\end{array}$ & $\begin{array}{c}8.03 \\
(22.09)\end{array}$ & $\begin{array}{c}3.41 \\
(9.38)\end{array}$ & $\begin{array}{l}36.35 \\
(100)\end{array}$ \\
\hline 2006-07(s) & $\begin{array}{c}45.47 \\
(77.47)\end{array}$ & $\begin{array}{c}31.84 \\
(54.25)\end{array}$ & $\begin{array}{c}13.62 \\
(23.20)\end{array}$ & $\begin{array}{c}10.09 \\
(17.19)\end{array}$ & $\begin{array}{c}3.63 \\
(6.18)\end{array}$ & $\begin{array}{l}58.69 \\
(100)\end{array}$ \\
\hline $\begin{array}{l}2007- \\
08 \text { (B.E) }\end{array}$ & $\begin{array}{c}47.11 \\
(82.89) \\
\end{array}$ & $\begin{array}{c}33.49 \\
(58.93)\end{array}$ & $\begin{array}{c}13.62 \\
(23.20)\end{array}$ & $\begin{array}{c}9.72 \\
(17.10)\end{array}$ & $\begin{array}{c}3.63 \\
(6.38)\end{array}$ & $\begin{array}{l}56.83 \\
(100)\end{array}$ \\
\hline $\begin{array}{l}\text { Average of } \\
1994-95,96- \\
97\end{array}$ & 18.14 & 15.07 & 0.06 & 1.98 & 0.776 & 17.12 \\
\hline $\begin{array}{l}\text { Average of } \\
2003-4, \\
2005-06\end{array}$ & 25.1 & 24.44 & 0.64 & 5.79 & 2.85 & 33.49 \\
\hline AACGR & 3.67 & 5.5 & 30.1 & 12.66 & 15.55 & 7.74 \\
\hline
\end{tabular}

Note: Values in brackets shows share of the revenue income

Source: Same as in Table 1

Non-tax revenue includes grant in aid from the state at the rate of 12.50, and general grant -in -aid received from the SFC.

The revenue from own taxes has increased at the rate of 3.64 percent p.a and that of non tax own revenue by 12.66 percent p.a. The octroi has been abolished and it has been substituted by compensation in lieu of octroi its share has declined from over 85 percent to 75 percent and the estimates for 2006-07, and 2007-08 show further decline to 55 percent. The property tax had a trend value of 30 percent between 1994-95 and 200506 but its share was only 2 percent. However, the budget estimates shows huge estimates and increase in the share to over 23 percent. Obviously, with the abolition of property tax it will not be achieved and the state government will have to compensate in lieu of the same. The non-tax own revenue trend is 12.66 percent p.a and its share is increasing which is presently 22 percent. We have separately shown the grant - in -aid received by JMC which includes general grant -in -aid given at the rate of Rs.12.50 per person as per the law for the purpose of salaries and wages and the general purpose grant given by the SFC. The share of this grant is around 10 percent with the actual figures but declines to 6 percent with the estimated figures. It has been growing at the rate of 15.55 percent. However, the actual figures of years 2004-05, 2005-06 and the estimates of 2006-07 and 2007-08 are almost constant. Third SFC will have to deal with these enforcing and abrupt changes because of the abolition of octroi and now the property tax.

\subsection{3: Trends in Revenue Expenditure}

The highest amount is spent on public health to the extent of about 70 percent of the total revenue expenditure. Expenditure on public health has increased at the rate of 9.81 percent p.a during this period. However, this increase in the expenditure on public health largely due to increases in the salaries and allowances. Infact, under all the heads the salaries and allowances account for 70-80 percent of the expenditure. There is nothing wrong in that because all these functions are labour intensive but the question is there adequate manpower, which can deliver these services to people efficiently and timely? As already mentioned that there is growing gap between the revenue income and revenue expenditure. The expenditure on the Department of tax collection has at present become redundant because of the abolition of octroi and house tax.This expenditure along with the manpower employed in them should be redeployed for some other priority area.

Table 3 gives trends in the revenue expenditure by various heads.

Table: 3

Trends in Revenue Expenditure by Various Heads - 1994-95 to 2007-08 (in Rs. Crores)

\begin{tabular}{|c|c|c|c|c|c|c|c|c|c|c|}
\hline Year & Gen. Ad & Taxation & $\begin{array}{l}\text { Public } \\
\text { Health }\end{array}$ & $\begin{array}{c}\text { Public } \\
\text { defense }\end{array}$ & $\begin{array}{c}\text { street } \\
\text { light }\end{array}$ & $\begin{array}{c}\text { Cattle } \\
\text { houses }\end{array}$ & Parks & $\begin{array}{l}\text { public } \\
\text { repair }\end{array}$ & Others & $\begin{array}{c}\text { Tota } \\
1\end{array}$ \\
\hline 1994-95 & $\begin{array}{c}0.29(2.6 \\
) \\
\end{array}$ & $\begin{array}{c}0.98(8.94 \\
) \\
\end{array}$ & $9.58(87.48)$ & $0.21(1.9)$ & $\begin{array}{c}0.53(4.84 \\
)\end{array}$ & $0.07(.63)$ & $\begin{array}{c}0.01(.09 \\
)\end{array}$ & $\begin{array}{c}0.25(2.28 \\
) \\
\end{array}$ & $0.01(.09)$ & $\begin{array}{c}10.9 \\
5 \\
\end{array}$ \\
\hline 1995-96 & $\begin{array}{c}1.12(8.9 \\
)\end{array}$ & $\begin{array}{c}1.19(9.52 \\
) \\
\end{array}$ & $8.7(69.5)$ & $0.25(2.0)$ & $\begin{array}{c}0.48(3.84 \\
) \\
\end{array}$ & $\begin{array}{c}0.14(1.12 \\
)\end{array}$ & $\begin{array}{c}0.02(.16 \\
)\end{array}$ & $\begin{array}{c}0.37(2.96 \\
)\end{array}$ & $\begin{array}{c}0.26(2.08 \\
)\end{array}$ & 12.5 \\
\hline 1996-97 & $\begin{array}{c}1.71(10.78 \\
)\end{array}$ & $1.35(8.5)$ & $\begin{array}{c}10.86(68.51 \\
)\end{array}$ & $\begin{array}{c}0.34(2.14 \\
) \\
\end{array}$ & $\begin{array}{c}0.85(5.36 \\
)\end{array}$ & $\begin{array}{c}0.18(1.13 \\
)\end{array}$ & $\begin{array}{c}0.03(.18 \\
)\end{array}$ & $0.5(3.15)$ & $0.01(.06)$ & $\begin{array}{c}15.8 \\
5\end{array}$ \\
\hline $1997-98$ & 1.46 & 1.37 & 12.76 & 0.31 & 0.69 & 0.17 & .03 & .49 & .10 & $\begin{array}{c}19.3 \\
9\end{array}$ \\
\hline 1998-99 & 3.48 & 2.37 & 20.61 & 0.91 & 3.79 & 0.28 & .08 & .89 & 0 & $\begin{array}{c}31.4 \\
3\end{array}$ \\
\hline $\begin{array}{l}1999- \\
2000\end{array}$ & $2(8.54)$ & $1.72(7.3)$ & $19.8(84.61)$ & $\begin{array}{c}0.45(1.92 \\
) \\
\end{array}$ & & $0.19(.81)$ & $\begin{array}{c}0.04(.17 \\
)\end{array}$ & $\begin{array}{c}0.56(2.39 \\
) \\
\end{array}$ & $0.2(.85)$ & 23.4 \\
\hline 2000-01 & $\begin{array}{c}1.64(6.4 \\
)\end{array}$ & $\begin{array}{c}1.93(7.52 \\
)\end{array}$ & $19.6(76.38)$ & $\begin{array}{c}0.65(2.53 \\
) \\
\end{array}$ & $\begin{array}{c}0.93(3.62 \\
)\end{array}$ & $0.18(.7)$ & $\begin{array}{c}0.04(.15 \\
)\end{array}$ & $\begin{array}{c}0.71(2.76 \\
)\end{array}$ & & $\begin{array}{c}26.1 \\
6\end{array}$ \\
\hline 2001-02 & $1.84(7)$ & $\begin{array}{c}1.84(6.91 \\
)\end{array}$ & $\begin{array}{c}19.81(74.50 \\
)\end{array}$ & $\begin{array}{c}0.74(2.78 \\
)\end{array}$ & $\begin{array}{c}0.98(3.68 \\
)\end{array}$ & $0.2(.75)$ & $\begin{array}{c}0.05(.18 \\
)\end{array}$ & $0.8(3.0)$ & & $\begin{array}{c}26.5 \\
9\end{array}$ \\
\hline 2002-03 & $1.85(7)$ & $1.87(6.70$ & $20.88(75.66$ & $0.81(2.93$ & $1.15(4.17$ & $0.21(.76)$ & $0.05(.18$ & $0.75(2.72$ & & 27.5 \\
\hline
\end{tabular}


Financial Health of Urban Local Bodies of Rajasthan with Special Reference to Jodhpur Municipal

\begin{tabular}{|c|c|c|c|c|c|c|c|c|c|c|}
\hline & & ) & ) & ) & ) & & ) & ) & & 6 \\
\hline 2003-04 & $\begin{array}{l}2.07(7.0 \\
4)\end{array}$ & $1.94(6.6)$ & $\begin{array}{c}22.61(76.95 \\
)\end{array}$ & $\begin{array}{c}0.81(2.93 \\
)\end{array}$ & $\begin{array}{c}0.85(2.89 \\
)\end{array}$ & $0.23(.78)$ & $\begin{array}{c}0.05(.17 \\
)\end{array}$ & $0.8(2.72)$ & & $\begin{array}{c}29.3 \\
8\end{array}$ \\
\hline 2004-05 & $\begin{array}{c}2.08(6.5 \\
) \\
\end{array}$ & $1.94(6.6)$ & $\begin{array}{c}24.17(76.41 \\
)\end{array}$ & $\begin{array}{c}0.85(2.68 \\
) \\
\end{array}$ & $\begin{array}{c}0.89(2.81 \\
) \\
\end{array}$ & $0.29(.91)$ & $\begin{array}{c}0.05(.16 \\
)\end{array}$ & $0.96(3.0)$ & $0.4(1.26)$ & $\begin{array}{c}31.6 \\
3 \\
\end{array}$ \\
\hline 2005-06 & $\begin{array}{c}3.16(8.7)(\mathrm{s} \\
)\end{array}$ & $\begin{array}{c}2.22(6.15 \\
)\end{array}$ & $\begin{array}{c}25.96(72.03 \\
)\end{array}$ & $\begin{array}{c}1.06(2.94 \\
)\end{array}$ & $\begin{array}{c}2.17(6.02 \\
)\end{array}$ & $0.39(.83)$ & $\begin{array}{c}0.06(.16 \\
)\end{array}$ & $\begin{array}{c}1.09(3.02 \\
)\end{array}$ & & $\begin{array}{c}36.0 \\
4\end{array}$ \\
\hline $\begin{array}{l}2006- \\
2007(\mathrm{~s})\end{array}$ & $\begin{array}{l}4.0(9.2)( \\
\mathrm{p})\end{array}$ & $\begin{array}{c}2.27(5.23 \\
)\end{array}$ & $\begin{array}{c}29.97(69.15 \\
)\end{array}$ & $\begin{array}{c}1.39(3.20 \\
)\end{array}$ & $3.6(8.3)$ & $0.4(.92)$ & $\begin{array}{c}0.17(.39 \\
)\end{array}$ & $\begin{array}{c}1.59(3.67 \\
)\end{array}$ & & $\begin{array}{c}43.3 \\
4 \\
\end{array}$ \\
\hline $2007-08$ & 2.96 & 2.44 & 30.35 & 1.19 & 4.16 & 0.31 & 0.16 & 1.44 & & \\
\hline $\begin{array}{l}\text { Average } \\
\text { of } \\
1994- \\
95,96- \\
97\end{array}$ & 1.04 & 1.17 & 9.71 & 0.27 & 0.62 & 0.13 & 0.02 & 0.37 & & 13.1 \\
\hline $\begin{array}{l}\text { Average } \\
\text { of } \\
2003- \\
4,2005- \\
06\end{array}$ & 2 & 2.03 & 22.55 & 0.82 & 1.30 & 0.243 & 0.05 & 1.11 & & $\begin{array}{c}32.3 \\
5\end{array}$ \\
\hline $\begin{array}{l}\text { AACG } \\
\mathrm{R} \\
\end{array}$ & 7.5 & 6.31 & 9.81 & 13.13 & 8.5 & 7.19 & 10.71 & 12.98 & & $\begin{array}{c}10.5 \\
6 \\
\end{array}$ \\
\hline
\end{tabular}

Source: As above

\subsubsection{Trends in Capital Income}

Table 4 shows trends in the capital income by its various components

Table: 4

Trends in Capital Income (Rs in Crores) Years 1994-95 to 2007-08.

\begin{tabular}{|l|c|c|c|c|c|}
\hline \multicolumn{1}{|c|}{ Year } & Sale of Land & Grant in aid & Borrowings & Others & Total \\
\hline $1994-95$ & $0.001(.08)$ & $0.61(48.41)$ & & $0.64(50.79)$ & 1.26 \\
\hline $1995-96$ & $0.001(.04)$ & $1.73(71.48)$ & & $0.69(28.51)$ & 2.42 \\
\hline $1996-97$ & $0.246 .3)$ & $2.55(67.28)$ & & $1(26.38)$ & 3.79 \\
\hline $1997-98$ & $.12(1.7)$ & $5.21(74.21)$ & & 1.68 & 7.02 \\
\hline $1998-99$ & $6.50(42.79)$ & $7.35(48.38)$ & & 1.34 & 15.19 \\
\hline $1999-2000$ & $0.04(1.16)$ & $1.56(45.61)$ & & $1.87(54.67)$ & 3.42 \\
\hline $2000-01$ & $1.66(31.14)$ & $1.67(31.33)$ & & $2.52(47.27)$ & 5.33 \\
\hline $2001-02$ & $0.8(9.5)$ & $5.32(63.78)$ & & $2.22(26.61)$ & 8.34 \\
\hline $2002-03$ & $1.67(30.92)$ & $2.18(40.37)$ & & $1.54(28.51)$ & 5.4 \\
\hline $2003-04$ & $1.04(13.95)$ & $2.56(34.36)$ & & $2.64(35.43)$ & 7.45 \\
\hline $2004-05$ & $1.13(12.61)$ & $4.47(49.88)$ & $1.2(16.10)$ & $1.75(19.53)$ & 8.96 \\
\hline $2005-06$ & $9.26(61.5)$ & $4.12(27.4)$ & & $1.73(14.74)$ & 15.04 \\
\hline 2006-07(s) & $27.45(67.94)$ & $8.32(20.59)$ & $0.5(1.2)$ & $2.63(6.5)$ & 40.4 \\
\hline 2007-08(B.E) & $14(57.70)$ & $7.63(31.45)$ & - & $2.63(8.65)$ & 24.26 \\
\hline Average of 1994-95,96-97 & .08 & 1.63 & $2(6.5)$ & 0.776 & 2.48 \\
\hline $\begin{array}{l}\text { Average of 2003-4,2005- } \\
\text { 06 }\end{array}$ & 1.28 & 3.07 & & & 1.97 \\
\hline AACGR & 36.07 & 7.28 & & & 10.48 \\
\hline
\end{tabular}

Source: Same as in Table 1

The highest growth is from the sale of land. Infact the increase in the sale from land has jumped 8-9 times in 2005-06. JMC proposes to accelerate this pace further in 2006-07, 2007-08. Prior to 2005-06 the income from this head remained around one crore only. This could be because of the increases in land prices and /or it could be that the total area of the land sold has increased or both. For this is necessary to know the area of the land being sold every year. The area of the land should be sold keeping in the mind the future generations and their needs. The rate of growth of receipts from capital grants in aid is 7.28 percent per annum. JMC expects that this will double in 2006-07 and 2007-08. This increase also could be because of the delayed release of capital funds from various agencies of the G.O.I and G.O.R and T.F.C and the S.F.C. We have seen earlier that the flow of capital income is very high compared to capital expenditure. This is the reflection of poor capacity of funds utilization or also could be due to inadequate planning. The head "others" includes the refund of the loans given to employees earlier and the flow is smooth and uniform.

\subsubsection{Trends in Capital Expenditure}

Table 5 shows the trends in capital expenditure. 
Table: 5

Trends in Capital Expenditure (in Rs Crores)

\begin{tabular}{|c|c|c|c|c|c|c|c|}
\hline \multirow[t]{2}{*}{ Year } & \multicolumn{3}{|c|}{$\begin{array}{c}\text { Development Works } \\
\text { (1) }\end{array}$} & \multirow[t]{2}{*}{$\begin{array}{c}\text { New Assets } \\
\text { (2) }\end{array}$} & \multirow{2}{*}{$\begin{array}{l}\text { Repayment of } \\
\text { Loans } \\
\text { (3) }\end{array}$} & \multirow[t]{2}{*}{$\begin{array}{l}\text { Misc. } \\
(4)\end{array}$} & \multirow[t]{2}{*}{$\begin{array}{c}\text { Total } \\
(5)\end{array}$} \\
\hline & JMC & Schemes & Total & & & & \\
\hline 1994-95 & 1.97 & 1.1 & 3.68 & $0.35(8.2)$ & $0.01(.23)$ & $0.81(19.10)$ & 4.24 \\
\hline $1995-96$ & 2.08 & 1.84 & 3.92 & $0.99(17.15)$ & $0.02(.34)$ & $0.85(14.73)$ & 5.77 \\
\hline 1996-97 & 6.25 & 1.53 & 7.78 & $0.48(5.0)$ & $0.01(.10)$ & $1.2(12.68)$ & 9.46 \\
\hline 1997-98 & 2.90 & 1.75 & 4.65 & .26 & 0.02 & 1.22 & 6.16 \\
\hline 1998-99@ & 7.80 & 8.28 & 16.08 & .49 & 0.10 & 1.41 & 18.08 \\
\hline $1999-2000$ & 0.95 & .45 & 1.45 & $0.01(.41)$ & $0.01(.41)$ & $0.94(39)$ & 2.41 \\
\hline $2000-01$ & 1.29 & 3.29 & 4.50 & $0.06(1.04)$ & $0.01(.17)$ & $1.17(20.34)$ & 5.75 \\
\hline $2001-02$ & 0.80 & 4.30 & 5.10 & $0.03(.37)$ & $0.02(.24)$ & $2.92(36.18)$ & 8.07 \\
\hline $2002-03$ & 0.62 & 4.50 & 5.12 & .05 & n.a & $1.77(25.54)$ & 6.93 \\
\hline $2003-04$ & 1.58 & 5.27 & 6.84 & $0.05(.72)$ & $0.05(.56)$ & $1.95(21.93)$ & 8.89 \\
\hline 2004-05 & 2.38 & 4.41 & 6.79 & $0.02(.23)$ & $0.21(2.5)$ & $1.4(16.62)$ & 8.42 \\
\hline $2005-06$ & .83 & 5.39 & 6.22 & $0.1(.46)$ & $1.22(5.6)$ & $2.71(12.35)$ & 12.98 \\
\hline 2006-07(s) & 16.55 & 12.95 & 29.50 & $0.71(1.68)$ & $5.65(13.42)$ & $3.67(8.72)$ & 42.08 \\
\hline 2007-08 & 9.85 & 12.34 & 22.19 & $.45(1.32)$ & $6.9(20.25)$ & $5.12(15.03)$ & 34.06 \\
\hline $\begin{array}{l}\text { Average of Three Years } \\
\text { from 1994-95to 96-97 }\end{array}$ & & & 4.94 & .606 & .013 & .0953 & 6.49 \\
\hline $\begin{array}{l}\text { Average of Three Years } \\
\text { 2003-04to2005-06 }\end{array}$ & & & 6.25 & 0.04 & & 1.7 & 10.09 \\
\hline AACGR & & & 2.64 & -26.06 & & 7.09 & 5.02 \\
\hline
\end{tabular}

Col.1: J.M.C development works include construction \& maintenance of roads, construction of urinals, parks, new electricity lines, etc.

Col. 2. Schemes consist of contributions of State, Central Government and municipality also and that of grants recommended under CFC. Different schemes are Swarna Jyanti Shahri Rojgar Yojna, National Housing and Slum Development Programme (NHSDP), Urban Integrated Development of Small and Medium Town -UIDSSMT etc,

Col.4. The head miscellaneous include recovery of securities and that of provisional advances, vehicle, house loans and food grain loans.

Source: Same as in Table 1

If we compare the various components of capital income and capital expenditure the budget is not given in the compatible manner. The JMC receives funds for different schemes from G.O.I and G.O.R and also its own funds, which they spend on development works, which are largely schemes, of state govt. and central govt. The proportion of the capital funds spent on these development works is 60-70 percent. The capital funds spent on the new assets are negligible.

\subsubsection{Trends in Per Capita Income and Expenditure}

Table 6 depicts trends in the per capita revenue and the capital income and per capita revenue and capital expenditure .The per capita revenue income has increased from Rs 226(three year average of 1994-95, 96 and 97) 1995-96 to Rs 349 (three year average 2003-4, 05, 06) at the rate of 4.94 percent p.a and the per capita revenue expenditure from Rs 172 to Rs 343 at the rate of 7.9 percent p.a. The per capita capital income increased by three times during this period from Rs. 32.to 113.7 however, the per capita expenditure increased by about 20 percent only. The per capita income increased by 14.85 percent p.a s compared to per capita capital expenditure increase of 2.11 percent, which is a reflection of poor utilization of funds. However, the sanctioned and the budget estimates for 2006-07 and 2007-08 in per capita terms do not justify the earlier actual figures. Either they are over- estimated or under- estimated which need a careful scrutiny. It is surprising that the sudden increase and sudden decline have not been explained as required under the law. There seems to be some kind of ad-hocism in the sanctioned and budget estimates. 
Table: 6

Trends in Per Capita Revenue and Capital Income \& Expenditure Years 1994-95 to 2007-08 (in current prices)

\begin{tabular}{|c|c|c|c|c|c|c|c|}
\hline Year & $\begin{array}{c}\text { Per } \\
\text { Capita } \\
\text { Revenue } \\
\text { Income }\end{array}$ & $\begin{array}{c}\text { Per } \\
\text { Capita } \\
\text { (Rev.Exp } \\
\text { ) }\end{array}$ & $\begin{array}{c}\text { Per } \\
\text { Capita } \\
\text { Capital } \\
\text { Income }\end{array}$ & $\begin{array}{l}\text { Per capita } \\
\text { (Cap.Exp) }\end{array}$ & $\begin{array}{c}\text { Per Capita } \\
\text { Total } \\
\text { Income }\end{array}$ & $\begin{array}{l}\text { Per } \\
\text { capita } \\
\text { Total } \\
\text { Exp }\end{array}$ & $\begin{array}{c}\text { Population } \\
\text { Estimated through } \\
\text { interpolation based } \\
\text { on AACGR } \\
\text { 1991-2001 }\end{array}$ \\
\hline 1994-95 & 182 & 148 & 17.1 & 57.76 & 199 & 206 & 7.34 \\
\hline 1995-96 & 252 & 166 & 32 & 78.6 & 284.72 & 242 & 7.53 \\
\hline 1996-97 & 244 & 204 & 48.96 & 122 & 293.5 & 326 & 7.74 \\
\hline $1997-98$ & 245 & 218 & 88.30 & 77.48 & 333.3 & 295 & 7.95 \\
\hline 1998-99 & n.a & n.a & n.a & n.a & n.a & n.a & 8.16 \\
\hline 1999-2000 & 265 & 279 & 63.6 & 28.7 & 306.92 & 307 & 8.38 \\
\hline 2000-01 & 282 & 297 & 96.7 & 93.7 & 344.36 & 364 & 8.61 \\
\hline 2001-02 & 330 & 295 & 60.9 & 101 & 425.22 & 387 & 8.84 \\
\hline $2002-03$ & 318 & 302 & 81.9 & 98.34 & 377 & 401 & 9.08 \\
\hline 2003-04 & 325 & 313 & 95.82 & 95.08 & 404 & 409 & 9.35 \\
\hline 2004-05 & 354 & 364 & 93.5 & 87.78 & 447 & 417 & 9.58 \\
\hline $2005-06$ & 369 & 354 & 152 & 131.9 & 522 & 427 & 9.84 \\
\hline $2006-07(\mathrm{~s})$ & 581 & 430 & 400 & 416 & 981 & 847 & 10.10 \\
\hline 2007-08(B.E) & 548 & 413 & 233 & 334 & 781 & 748 & 10.37 \\
\hline $\begin{array}{l}\text { Three Year } \\
\text { Average of 1994- } \\
95 \text { to } 96-97\end{array}$ & 226 & 172 & 32.68 & 86.12 & 259 & 258 & \\
\hline $\begin{array}{l}\text { Average of 2003- } \\
04,2005-06\end{array}$ & 349 & 343 & 113.7 & 104.92 & 457 & 431 & \\
\hline AACGR & 4.94 & 7.9 & 14.85 & 2.11 & 6.51 & 5.06 & \\
\hline
\end{tabular}

\subsubsection{Trends in Revenue Grant-in-aid and Capital Grants}

Table 7 presents the trends in Revenue grant-in-aid and capital grants. The revenue grant-in -aid has increased at the rate of 15.55 percent largely due to wage increases but its percentage share to revenue income is relatively low at 10 percent only. However, the percentage of capital grant to capital income has increased at the rate of 7.28 percent p.a but its percentage to capital income and capital expenditure is fluctuating but quite high. At present the dependence of JMC on these grants is relatively not very high but with the abolition of octroi and property tax there will be substantial dependence on the grants from the state govt and G.O.I. The G.O.R. has already started the classifying the compensation in lieu of octroi as grant in aid. If that is so then dependence on the grant in aid increases substantially.

Table: 7

Revenue grant-in-aid and the Capital grant-in-aid

\begin{tabular}{|c|c|c|c|c|}
\hline Year & $\begin{array}{c}\text { Revenue Grant-in - } \\
\text { aid (\% of revenue } \\
\text { income) }\end{array}$ & $\begin{array}{l}\text { Capital Grant -in-aid } \\
\text { as \% of Capital Income }\end{array}$ & $\begin{array}{l}\text { Revenue grant -in -aid } \\
\text { as \% of Revenue Exp }\end{array}$ & $\begin{array}{c}\text { Capital grant -in - } \\
\text { aid as \% of Capital } \\
\text { Exp }\end{array}$ \\
\hline 1994-95 & $0.67(5)$ & $0.61(48.41)$ & 6.11 & 14.38 \\
\hline $1995-96$ & $0.83(4.3)$ & $1.73(71.48)$ & 6.64 & 29.98 \\
\hline 1996-97 & $0.83(4.3)$ & $2.55(67.28)$ & 5.23 & 26.95 \\
\hline $1997-98$ & $1.25(6.41)$ & $5.21(74.21)$ & 6.44 & 84.57 \\
\hline 1998-99 & $1.53(4.8)$ & $7.35(48.38)$ & 4.86 & 40.65 \\
\hline $1999-2000$ & $1.56(7.0)$ & $1.56(45.61)$ & 6.66 & 64.73 \\
\hline $2000-01$ & $0.83(3.4)$ & $1.67(31.33)$ & 3.23 & 27.8 \\
\hline 2001-02 & $4(13.6)$ & $5.32(63.78)$ & 15.04 & 65.92 \\
\hline $2002-03$ & $2.46(8.60)$ & $2.18(40.37)$ & 8.47 & 31.45 \\
\hline 2003-04 & $2.49(8.19)$ & $2.56(34.36)$ & 8.92 & 28.92 \\
\hline 2004-05 & $3.42(10.13)$ & $4.47(49.88)$ & 10.81 & 53.08 \\
\hline $2005-06$ & $3.41(9.38)$ & $4.12(27.4)$ & 10.07 & 31.74 \\
\hline 2006-07(s) & $3.63(6.18)$ & $8.32(37.36)$ & 8.37 & 19.77 \\
\hline 2007-08(B.E) & $3.63(6.38)$ & $7.63(31.45)$ & 8.44 & 22.40 \\
\hline $\begin{array}{l}\text { Average of Three Years } \\
\text { from 1994-95 to 96-97 }\end{array}$ & 0.776 & 1.63 & & \\
\hline $\begin{array}{c}\text { Average of Three Years } \\
2003-04 \text { to } 2005-06\end{array}$ & 2.85 & 3.07 & & \\
\hline AACGR & 15.55 & 7.28 & & \\
\hline
\end{tabular}




\subsubsection{Expenditure on Salaries and Allowances}

Table 8 shows expenditure on salaries and allowances of JMC during 1994-95 to 2007-08. Salary bill has doubled during this period and allowances have increased by 2.5 times. The salary and allowances is 83 percent of the revenue receipts. Such a high wage bill leaves very little room for revenue surplus and it increases the dependence on grants for development purposes.

Table: 8

Expenditure on Salaries and allowance of employees of JMC

\begin{tabular}{|c|c|c|c|}
\hline Year & $\begin{array}{c}\text { Salaries } \\
\text { (1) }\end{array}$ & $\begin{array}{c}\text { D.A \& } \\
\text { Allowances } \\
(2) \\
\end{array}$ & $\begin{array}{c}1+2 \text { as } \% \text { of } \\
\text { revenue receipts }\end{array}$ \\
\hline 1994-95 & 7.81 & 1.33 & 68.37 \\
\hline $1995-96$ & 9.11 & 1.04 & 53.40 \\
\hline 1996-97 & 11.83 & 1.30 & 69.46 \\
\hline $1997-98$ & 13.59 & 1.52 & 77.57 \\
\hline 1998-99 & 22.37 & 1.72 & \\
\hline $99-2000$ & 18.66 & 2.55 & 99.83 \\
\hline $2000-01$ & 19.85 & 2.68 & 92.68 \\
\hline $2001-02$ & 19.85 & 2.63 & 76.88 \\
\hline $2002-03$ & 21.04 & 2.63 & 82.79 \\
\hline 2003-04 & 22.48 & 2.76 & 83.10 \\
\hline 2004-05 & 24.59 & 3.52 & 83.36 \\
\hline $2005-06$ & - & - & - \\
\hline 2006-07(s) & - & - & - \\
\hline $2007-08$ & - & - & - \\
\hline $\begin{array}{l}\text { Average of Three } \\
\text { Years from 1994- } \\
95,96-97\end{array}$ & 9.58 & 1.22 & \\
\hline $\begin{array}{l}\text { Average of Three } \\
\text { Years 2002-03to } \\
\text { 2004-05 }\end{array}$ & 22.70 & 2.97 & \\
\hline AACGR & 10.05 & 10.39 & \\
\hline
\end{tabular}

\section{Conclusions}

Stemming from the above analyses it is evident that rate of the growth of revenue income of J.M.C is lower than that of the revenue expenditures, indicating worsening financial health of J.M.C. Also rate of growth of capital income is significantly higher than the rate of growth of capital expenditure, which indicates underutilization of available resources which again obstructs to achieve the productive efficiency. The two main sources of its own taxes have been abolished first in 1998 and second from February 2007. In case of the octroi government is compensating J.M.C through grant to be increased by 10 percent annually on the basis of octroi income of 1997-98. However, they are increasing the compensation by 5 percent thus further reducing the resources of JMC. Flow of grants is not uniformly spread over the years and so there would be financial crunch. It is released at the end of the fag financial year hence it cannot be utilized in the same year. There is a vast difference between the budget proposals, the sanctioned amount and the actual. This is an indication of poor collections as well as poor utilization of resources. The wages and allowances account for over 83 percent of the revenue income. If we include establishment expenditure also it will increase to nearly 90 percent. By law they are supposed to show a balance of one twelfth of their revenue income hence there is no revenue surplus. Obviously, this will affect the development works of JMC. The Constitutional mandate is to give functional and financial autonomy to elected local bodies so as to make effective instrument of decentralization. However, the present framework does not allow this. The local bodies in Rajasthan are highly controlled and regulated by government. The State Finance Commisssion (SFC) needs to give recommendations in consonance with constitutional mandate. The SFC should estimate the needs of local bodies and make recommendations accordingly. State government should accept and implement the recommendations of State Finance Commissions. It has not happened yet. It seems that even local bodies have not effectively demanded its due as a constitutional entity from the SFC.

\section{References}

[1]. Annual Progress Report, Government of Rajasthan, Department of Local Self Government. (Different years).

[2]. Jodhpur Municipal Corporation's Budget of different years.

[3]. Jodhpur Master Plan 2001-2023, Department of Town Planning, Government of Rajasthan.

[4]. Report of the Second State Finance Commission of Rajasthan, Government of Rajasthan (2000-2005)

[5]. Thakur, S. Evaluating the Financial Health of Indian Cities: A Diagnostic Report .

[6]. (www.niua.org/upcoming\%20seminars/SANDEEP-24JULY-FINANCE.pdf).

[7]. Twelfth Finance Commission, Government of India, Local Bodies, Chapter 8 and its relevant Annexure. 